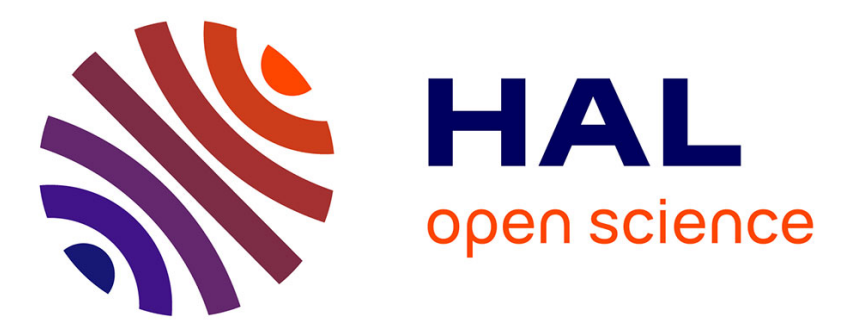

\title{
Polybrominated diphenyl ethers (PBDEs) in seal populations from eastern and western Canada: an assessment of the processes and factors controlling PBDE distribution in seals
}

\author{
M.G. Ikonomou, R.F. Addison
}

\section{To cite this version:}

M.G. Ikonomou, R.F. Addison. Polybrominated diphenyl ethers (PBDEs) in seal populations from eastern and western Canada: an assessment of the processes and factors controlling PBDE distribution in seals. Marine Environmental Research, 2008, 66 (2), pp.225. 10.1016/j.marenvres.2008.02.004 . hal-00563003

\section{HAL Id: hal-00563003 \\ https://hal.science/hal-00563003}

Submitted on 4 Feb 2011

HAL is a multi-disciplinary open access archive for the deposit and dissemination of scientific research documents, whether they are published or not. The documents may come from teaching and research institutions in France or abroad, or from public or private research centers.
L'archive ouverte pluridisciplinaire HAL, est destinée au dépôt et à la diffusion de documents scientifiques de niveau recherche, publiés ou non, émanant des établissements d'enseignement et de recherche français ou étrangers, des laboratoires publics ou privés. 


\section{Accepted Manuscript}

Polybrominated diphenyl ethers (PBDEs) in seal populations from eastern and western Canada: an assessment of the processes and factors controlling PBDE distribution in seals

M.G. Ikonomou, R.F. Addison

PII:

S0141-1136(08)00020-2

DOI: 10.1016/j.marenvres.2008.02.004

Reference: MERE 3172

To appear in:

Marine Environmental Research

Received Date:

2 April 2007

Revised Date:

10 October 2007

Accepted Date:

9 February 2008

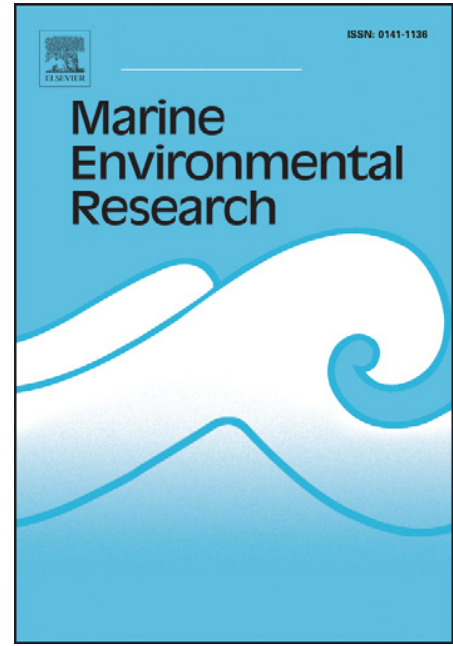

Please cite this article as: Ikonomou, M.G., Addison, R.F., Polybrominated diphenyl ethers (PBDEs) in seal populations from eastern and western Canada: an assessment of the processes and factors controlling PBDE distribution in seals, Marine Environmental Research (2008), doi: 10.1016/j.marenvres.2008.02.004

This is a PDF file of an unedited manuscript that has been accepted for publication. As a service to our customers we are providing this early version of the manuscript. The manuscript will undergo copyediting, typesetting, and review of the resulting proof before it is published in its final form. Please note that during the production process errors may be discovered which could affect the content, and all legal disclaimers that apply to the journal pertain. 
3 Polybrominated diphenyl ethers (PBDEs) in seal populations from eastern and western

4 Canada: an assessment of the processes and factors controlling PBDE distribution in seals.

$9{ }^{1}$ Department of Fisheries and Oceans, Institute of Ocean Sciences, 9860 West Saanich Road,

$12{ }^{2}$ R.F. Addison Environmental Consulting Ltd. 121 Graham Drive, Saltspring Is., BC,

24 * corresponding author: tel.: (250) 363-6804; e-mail: ikonomoum@dfo-mpo.gc.ca 


\begin{abstract}
Polybrominated diphenyl ether (PBDE) concentrations were measured in the blubber of five mother-pup pairs of grey seals (Halichoerus grypus) from Sable Island, Nova Scotia (NS) sampled in 1995 and in 20 British Columbia (BC) sampled in 1991-92. Concentrations in maternal grey seals from Sable Is. averaged $113 \pm 55.2 \mathrm{ng} / \mathrm{g}$ lipid (mean \pm s.d.) and were over twice the concentrations measured in their pups; lower brominated PBDEs showed a distinct decline in PBDEs transfer efficiency in motherpup pairs as a function of increasing $\mathrm{K}_{\mathrm{o} / \mathrm{w}}$. Hepta-BDEs and higher molecular weight (MW) congeners appear not to be transferred efficiently from the grey seals mother to pup during lactation on the basis of lipid/water partitioning (as indicated by $\ln \mathrm{K}_{\mathrm{o} / \mathrm{w}}$ ) and this may be a consequence of molecular size (MW >600 Daltons) which may limit diffusion and partitioning. PBDE concentrations in blubber from harbour seals from the Strait of Georgia averaged $319 \pm 132 \mathrm{ng} / \mathrm{g}$ lipid (mean \pm s.d., $\mathrm{n}=13$ ), while those from the more remote and less contaminated Quatsino Sd. averaged $27.8 \pm 11.8$ ng/g (mean \pm s.d., $n=7$ ). Tri- to hexa- BDEs were appreciably enriched in Strait of Georgia harbour seals relative to those from Quatsino Sd, suggesting that the former were closer to PBDE sources. The main congeners identified in all samples were BDEs 47, 99, 100, 153 and 154. Data were compared to those in ringed seals sampled from Holman, North West Territories (NWT), in 1996. The Holman samples had a higher proportion of lower bromination congeners, and a lower proportion of higher bromination congeners, than did the Sable Island and BC seal samples, consistent with selection in favour of more volatile compounds during atmospheric transport to the Arctic.
\end{abstract}




\section{1. Introduction}

2 For approximately the last decade polybrominated diphenyl ethers have been

3 identified as pollutants of growing concern. These chemicals have been used since the 1980's,

4 and continue to be used though under increasingly restricted conditions (Hites, 2004; de Wit

5 et al., 2006) mainly as flame retardants in fabrics and other materials. Like other organic

6 pollutants, PBDEs accumulate in higher trophic level-feeding marine biota, and have been

7 described in marine mammals from eastern and western Canada, and in populations far

8 removed from local PBDE sources (Ikonomou et al., 2002; Rayne et al., 2004; Lebeuf et al.,

9 2004; de Wit et al., 2006).

10 In this paper, we describe PBDE distribution in mother-pup pairs of grey seals

11 (Halichoerus grypus) from Sable Island NS, sampled in 1995 and in two populations of

12 harbour seals (Phoca vitulina) sampled from the BC coast in 1991-92; both populations were

13 sampled previously to provide information on contamination by polychlorinated biphenyls

14 (PCBs) and polychlorinated dibenzo- $p$-dioxins and furans, but no data have been published

15 describing their PBDE contamination.

16 We compare the distribution of PBDEs with that of legacy POPs measured in these

17 samples, and with PBDEs and other organic pollutants in other seal populations from various

18 sites in Canada and elsewhere. Since the production and use of PBDEs changed rapidly

19 between 1980 and 2000 (e.g., Ikonomou et al., 2002) our comparisons have focussed

20 deliberately on samples taken only during the fairly narrow interval of 1991-92 (harbour

21 seals) and 1995 (Sable Island grey seals). We have also compared these data to PBDE

22 concentrations in Holman ringed seals sampled in 1996 and published elsewhere (Ikonomou

23 et al., 2002). These comparisons allow us to assess the processes and factors which control

24 the exposure of seals to these chemicals and their distribution in seals. The data sets 
1 compared in this paper captures most of the Canadian seals PBDE data published so far, and

2 since all the samples were analyzed by the same laboratory following the same analytical 3 protocols the analytical data are internally consistent.

\section{2. Materials and Methods}

Blubber from five isolated mother-pup pairs of grey seals were sampled on Sable

7 Island in February 1995. Detailed sample information can be found in Addison et al. (1999).

8 (Mother-pup pair 149204 was omitted from PBDE analyses.) The samples had previously

9 been analysed for residues of polychlorinated biphenyls (PCBs) and for polychlorinated

10 dibenzo-dioxins and furans (PCDD/F) (Addison et al., 1999) and the archived extracts from

11 these analyses were re-analysed for PBDEs. Blubber was sampled from harbour seals in

12 1991-92 from the Strait of Georgia, and from Quatsino Sd., Vancouver Island. These animals

13 were shot as predators on fish farms, and so variables such as sex and age could not be

14 controlled. The blubber samples were analysed for PCBs and PCDD/F (Addison et al., 2005)

15 and 20 archived extracts from these analyses were re-analysed for PBDEs. Figure 1 shows

16 the location of the sampling sites, and of Holman, NWT. The archived extracts for both the

17 Sable Island and the west coast samples (Strait of Georgia, and Quatsino Sd) were stored in 18 amber vials in the dark at $-20^{\circ} \mathrm{C}$.

19 As noted above, both the grey seal and the harbour seal samples were analyzed for

20 PCBs and PCDD/Fs as part of other studies. The sample extraction and clean-up procedures

21 used to process the samples for PCBs and PCDD/Fs have been described in detail elsewhere

22 (Ikonomou et al., 2001). Four fractions were collected from each of the samples and those

23 were analyzed for target PCBs and PCDD/Fs by high-resolution gas chromatography high-

24 resolution mass spectrometry (HRGC-HRMS). Following these analyses the four fractions 
1 were combined, spiked with a suite of ${ }^{13} \mathrm{C}$-labeled PBDE standards (method internal and

2 performance) and analyzed for mono- to hepta-BDEs by HRGC-HRMS. The extracts from

3 the Sable Island samples were analyzed for octa- to deca-BDEs as well but the concentrations

4 measured were close to the levels measured in the procedural blanks and thus not reported.

5 The composition of the ${ }^{13} \mathrm{C}$-labelled PBDE standards used for quantification, the instrumental

6 analysis conditions used, the quantification protocols, the criteria used for congener

7 identification, and the quality assurance/quality control (QA/QC) measures undertaken for

8 the HRGC-HRMS analysis of PBDE target analytes are described in detail elsewhere

9 (Ikonomou et al. 2001 and 2002). Since the samples were not spiked at the extraction step

10 with labelled PBDE internal standards, percent recoveries of the PBDE method internal

11 standards were unknown. However, extensive method validation experiments with this matrix

12 have enabled us to confirm that the extraction efficiency of the PCBs and PBDEs are similar

13 under the experimental conditions used. Therefore, we used percent recoveries of the labelled

14 PCB internal standards, obtained from the corresponding analyses described above, to

15 establish the percent recoveries of the labelled PBDEs internal standards and to quantify the

16 native PBDE concentrations accordingly. The mono- to hepta-BDE levels measured in the

17 procedural blanks associated with the analysis of these samples totalled $3500 \mathrm{pg} / \mathrm{g}$ and were

18 accounted for mainly by BDE 138/166 (2000 pg/g) and BDE 140 (1000 pg/g). Detection

19 limits for the Sable Is. grey seal analyses were in the range $1.6 \mathrm{pg} / \mathrm{g}$ (mono- and hepta-BDEs)

20 to $13.7 \mathrm{pg} / \mathrm{g}$ (penta-BDEs) and for the $\mathrm{BC}$ harbour seal analyses were in the range $0.6 \mathrm{pg} / \mathrm{g}$

21 (mono- and penta-BDEs) to $21.5 \mathrm{pg} / \mathrm{g}$ (hexa-BDEs). The concentrations of the mono- to

22 hepta-BDE congeners measured in all the samples were orders of magnitude higher than

23 those measured in the blanks and the data were not blank corrected. 
To provide information about the importance of atmospheric transport in controlling

2 the distribution of PBDEs in seal populations, data from these analyses were compared in

3 detail with data from ringed seals (Phoca hispida) from Holman, NWT, sampled in 1996

4 details of which can be found in Ikonomou et al., 2002. Data were analysed using software

5 from Statistica (Statsoft, OK).

6

\section{3. Results}

\subsection{PBDE residues in Sable Island grey seals.}

The PBDE concentrations of the all the congener groups for the five mother-pup pairs examined in this study are summarized in Table 1. Total PBDEs were distributed normally

12 (Kolmogorov-Smirnov test) in both mothers and pups. Total PBDE concentrations were 13 around $110 \mathrm{ng} / \mathrm{g}$ wet weight in maternal blubber, and about $46 \mathrm{ng} / \mathrm{g}$ wet weight in pups. No 14 mono-BDEs were detected, and only BDE 15 was detected among the di-BDEs. The main 15 tri-BDE was the pair BDE 28/33 which accounted for about $80 \%$ of this group. BDE 47 16 comprised over $90 \%$ of the tetra-BDEs, and BDE 99 and BDE 100 represented (respectively) 17 about $50 \%$ and $40 \%$ of the penta-BDEs. Similarly, BDE 153 and 154 represented about 50\% 18 and $40 \%$ respectively of the hexa-BDEs. Tetra-, penta-, and hexa-BDEs represented 19 (respectively) about $62 \%, 18 \%$ and $18 \%$ of total BDEs in mothers; because of differences in

20 the "transfer efficiency" of these compounds from mother to pup via milk, discussed in detail 21 below, these three congener groups in the pup represented about 79\%, $14 \%$ and $5 \%$ of the 22 total. Only traces of hepta- and higher PBDEs were found in either mother or pup. Figure 2 23 summarises the major individual BDE congener concentrations in mothers and pups. 
Total PBDE concentrations in adult female grey seals showed no statistically

2 significant variation with age, but sample size was small $(n=5)$.

The transfer of PBDE from mother to pup during lactation declined consistently with

4 increasing $\mathrm{Br}$ substitution from di- to hexa-BDE, and then levelled off (Table 1). However,

5 variance in the concentrations of higher BDE groups (above hexa-BDE) was high (s.d.

6 usually about equal to the mean, whereas in di- to hexa-BDEs, s.d. was about $60 \%$ of the

7 mean) perhaps due partly to the fact that concentrations were approaching the detection limit.

8 This increasing variance in higher BDE congener groups may have skewed the relationship

9 with increasing bromination. Figure 3 shows a plot of mean $\%$ transfer of di- to hepta-BDE

10 from mother to pup versus $\ln \mathrm{K}_{\mathrm{o} / \mathrm{w}}$ (calculated from data of Braekevelt et al., 2003).

3. 2. PBDE residues in British Columbia harbour seals.

13 The total PBDE concentrations of the major PBDE congener groups measured in two 14 populations of harbour seals are summarized in Table 2. Again, total PBDEs were distributed 15 normally in both Strait of Georgia and Quatsino Sd. sample sets. PBDE concentrations 16 differed widely in the blubber of harbour seals from these two populations, with tetra- and 17 penta-BDEs in samples from the Strait of Georgia being more than an order of magnitude 18 higher than those in Quatsino Sd. samples. Differences in tri-, hexa- and hepta-BDEs, 19 although large, are more probably related to general "background" contamination. As noted 20 previously (Addison et al., 2005) the Strait of Georgia samples had about half the blubber

21 thickness of the Quatsino Sd. samples, so the PBDE burden (as opposed to concentration) of 22 the former would probably be only about five times as great as in the latter. There was little 23 difference between the sexes in total PBDE concentrations at either site: in Strait of Georgia 24 samples, females contained $306 \pm 99 \mathrm{ng} / \mathrm{g}$ lipid (mean \pm s.d., $\mathrm{n}=9$ ) and males $348 \pm 205 \mathrm{ng} / \mathrm{g}$ 
1 lipid ( $\mathrm{n}=4)$ in Quatsino Sd., females contained $26 \pm 19 \mathrm{ng} / \mathrm{g}$ lipid $(\mathrm{n}=3)$ and males $29 \pm 6 \mathrm{ng} / \mathrm{g}$

2 lipid $(n=4)$. Sample sizes were too small, and the range of ages covered too large, for the

3 possible effect of age on sex differences to be detected. The distribution of the six major

4 congeners in the two sample sets are presented in Fig. 4; BDE 47 (representing $>98 \%$ of

5 tetra-BDEs), BDE 99 and 100 (65-75\% and 23-33\% of penta-BDEs), BDE 153 and 154 (63-

$686 \%$ and $9-23 \%$ of hexa-BDEs) and BDE 183 ( $>90 \%$ of hepta-BDEs) predominated. Table

72 also shows that there was a considerable enrichment of tetra- and penta-BDEs, and

8 possibly of tri- and hexa-BDEs, in the Strait of Georgia samples.

9 In Strait of Georgia female harbour seals $(n=9)$ there was no statistically significant

10 variation with age. Sample sizes of male seals in the two BC harbour seal populations were

11 too small $(n=4)$ to undertake regression analyses.

\section{4. Discussion}

14 Of the three populations sampled, the harbour seals from the Strait of Georgia had the 15 highest total blubber PBDE concentrations ( $>300 \mathrm{ng} / \mathrm{g}$ lipid). These total concentrations are 16 in the same range as those reported in harbour seals from the San Francisco area in 1989 and 171993 (She et al, 2002) but slightly lower than those found in North Sea harbour seals (Boon 18 et al., 2002), and generally lower than killer whales and porpoise from the same general area

19 (Ikonomou et al., 2002; Rayne et al., 2004). Sable Island grey seals had appreciably lower

20 total PBDE concentrations (>100 ng/g lipid in adult females); these concentrations are similar 21 to those reported for female northern fur seals collected in the mid-1990's from northern 22 Japan (Kajiwara et al., 2004) but slightly lower than those reported for European gray seals in 23 the early to mid-1990's (Law et al., 2003). Harbour seals from Quatsino Sd. had the lowest 24 total PBDE concentrations (<30 ng/g lipid); these concentrations are below most of those 
1 reported in any marine mammals from northern hemisphere mid-latitudes, but more than an

2 order of magnitude higher than concentrations in western Arctic ringed seals sampled in the 3 mid-1990's (Ikonomou et al, 2002). The distribution of the major PBDE congeners, with 4 BDE 47 predominant followed by BDEs 99 and 100 (Fig. 1) is similar to that reported for 5 other north American marine mammals and probably reflects (mainly) the use of the "penta" 6 PBDE mixture in North America.

The distribution of POPs (exemplified by PCBs and the DDT group) in seals is 8 controlled by external factors such as exposure (usually through diet) and endogenous factors 9 such as the age, sex and condition of the animals (Addison, 1989). In the case of the Sable 10 Island grey seal pups, for practical purposes the only exposure route is ingestion of maternal 11 milk. There may be some deposition of residues during foetal development, but this is very 12 small in comparison to exposure through lactation. "Transfer efficiency" of PBDEs from 13 mother to pup via lactation showed a clear decline with increasing $\mathrm{K}_{\mathrm{o} / \mathrm{w}}$ (Fig. 3) but the 14 relationship failed beyond the hexa-BDEs, as noted above. Braekevelt et al. (2003) have 15 noted that the generally linear relationship between $\mathrm{Br}$ substitution and $\ln \mathrm{K}_{\mathrm{o} / \mathrm{w}}$ also tends to 16 become asymptotic beyond hepta-BDEs. The factors which govern the transfer from mother 17 to pup of hepta-BDEs and higher are not clear: it may be significant that hexa- and hepta18 BDEs have MW of 698 and 786 Daltons, respectively, and there is evidence the transport of 19 lipophilic compounds of MW above about 600 Daltons across biological membranes may be 20 difficult (e.g., Niimi and Oliver, 1988). The process of transfer may be further complicated 21 by the fact that some re-synthesis of lipid in mammary tissue may take place (Iverson et al, 22 1995). The transfer of PBDEs, particularly the higher congeners, from mother to pup via 23 milk is therefore not simply a process of diffusion and partition.. A similar reduction in 24 transfer from mother to pup in higher congener groups was also observed with mono-ortho- 
1 PCBs and (Addison et al., 1999) and was attributed to increasing octanol-water partition

2 coefficient $\left(\mathrm{K}_{\mathrm{o} / \mathrm{w}}\right)$ with increasing $\mathrm{Cl}$ substitution (or increasing MW or molecular size, all of

3 which co-vary); this implied increase in lipid solubility with increasing $\mathrm{Cl}$ substitution would

4 probably reduce partitioning into blood, which is the first step in transfer of POPs residues

5 from blubber into milk. Similar factors appear to govern the transfer of at least the lower

6 PBDE congener groups from mother to pup.

7 Total PBDE transfer from mother to pup was $44.4 \pm 9.9 \%(n=5)$. This is fairly similar

8 to the transfer of PCBs which were estimated to be in the $30-40 \%$ range but probably less

9 than DDT-group transfer (40-60\%: Addison and Brodie, 1977; 1987).

10 In adult seals, the main route of exposure to POPs must be through diet, whose

11 contamination in turn depends on various inputs which would include at a minimum local

12 (perhaps "point source") discharges, and/or long range atmospheric or advective transport.

13 Comparison of the PBDE congener distribution patterns in the seal population discussed here,

14 and with others, allows us to infer something about the relative importance of these sources.

15 Consider first the BC harbour seals: the Strait of Georgia represents the "receiving waters"

16 for industrial and municipal discharges from the greater Vancouver and SE Vancouver Island

17 area (approximate population 3M). Quatsino Sd. is a relatively remote inlet in western

18 Vancouver Island, receiving wastes only from the small community of Port Alice and a local

19 pulp mill. In previous analyses (Addison et al. 2005) it was shown that the polychlorinated

20 dibenzo- dioxin and furan $(\mathrm{PCDD} / \mathrm{F})$ distribution in these samples reflected both the expected

21 qualitative and quantitative differences in discharges of industrial wastes in these two areas.

22 Thus, total PCDD and PCDF burdens in the Strait of Georgia samples were estimated to be

23 (respectively) about 8-fold and 3-fold higher than in Quatsino Sd.; furthermore, enrichment

24 of 1,2,3,6,7,8-hexachlorodibenzo-p-dioxin and 2,3,7,8-tetrachlorodibenzofuran (both of 
1 which were characteristic of bleached kraft mill discharges during the 1990's) in the Strait of

2 Georgia samples identified such effluents as a significant source of these chemicals. In other

3 words, the PCDD/F data show that these two seal populations reliably reflect quantitative and

4 qualitative differences in local contaminant sources. The relative distribution of PBDEs in

5 the two harbour seal populations follows the pattern of PCDD/F; i.e., total PBDE

6 concentrations were about 11-fold higher in the Strait of Georgia samples than in Quatsino

7 Sd., corresponding to a difference in residue burdens (because of differences in condition of

8 the two samples: see Addison et al, 2005 for a discussion) of about 5-fold. Furthermore, the

9 relative enrichment of tri- to hepta-BDEs in the Strait of Georgia suggests that these samples

10 may have been closer to the putative source of PBDEs in the Strait of Georgia. However,

11 when congener group distribution is expressed as a percentage of total PBDEs, there is little

12 evidence in favour of the skewing of PBDEs in Quatsino Sd. samples in favour of lower MW

13 (and hence more volatile) components (Fig. 4). This suggests that atmospheric transport may

14 not be a significant route of transport of PBDEs into Quatsino Sd.

15 Sable Island is considered relatively remote and free from local sources of 16 contamination; nevertheless, it is both downstream and downwind from the St. Lawrence

17 basin which represents a large urbanised and industrialised area. Bidleman et al., (1992)

18 have documented atmospheric transport of contaminants into Sable Island via the prevailing

19 westerly winds, and either atmospheric or water advective transport (or both) probably

20 contributed to contamination of the gray seal population by DDT and its degradation products

21 (Addison and Stobo, 2001). Mean total PBDE concentrations were lower than in the Strait of

22 Georgia harbour seals, which would be expected given Sable Island's relative remoteness;

23 however a potentially confounding factor is the fact that grey seals and harbour seals may

24 feed at slightly different trophic levels, or may differ in their capacity for metabolic 
1 degradation of compounds such as PBDEs. The relative distribution of the main PBDE

2 congener groups (Fig. 5) did not differ appreciably between the Sable Island grey seals and

3 the $\mathrm{BC}$ harbour seals, which suggests that "sorting" of PBDE congeners on the basis of their

4 vapour pressure or other physico-chemical properties is relatively unimportant.

5 In contrast, comparison of the Sable Island grey seal data and the BC harbour seal

6 data with data from western Arctic ringed seals illustrates the probable importance of

7 atmospheric transport in introducing PBDEs to the Arctic. Figure 5 shows the main congener

8 group distribution in ringed seals compared to those in the Sable Island and BC seals: it is

9 clear that lower brominated PBDEs represent a higher fraction of total PBDEs, and higher

10 brominated groups a lower fraction, in the Arctic ringed seals. This suggests that there has

11 probably been some "sorting" of the supply of PBDEs to the western Arctic which is based

12 on congener volatility; this is not seen over the shorter distribution routes to Quatsino Sd. or

13 to Sable Island.

14 Finally, the role of metabolic degradation and the significance of trophic level are

15 factors which must be considered in making inter-species comparisons, as we have done here.

16 At first sight, grey seals may appear to function at a higher trophic level than the other two

17 species, as they face no direct predators, unlike the harbour and ringed seas which are preyed

18 on by (respectively) killer whales and polar bears. In practice, however, all three seal species

19 are, to a varying extent, fairly opportunistic feeders, and feed on small- to medium-sized fish

20 and large invertebrates (e.g., Smith, 1987; Addison and Stobo, 2001; ) and have been

21 assigned to similar trophic levels based on dietary analyses (Pauly et al., 1998). In this sense,

22 our inter-species comparisons are justified. The role of metabolic degradation in controlling

23 PBDE congener distribution is more difficult to assess. Experimental studies on BDE

24 congener metabolism by aquatic species has been limited to studies on fish, from which it has 
1 been inferred from comparative congener distribution and from the occurrence of

2 hydroxylated and methoxylated metabolites that some degradative capacity exists (e.g.,

3 Stapleton et al., 2004a, b; Isosaari et al. 2005) though it is recognised that some of the

4 methoxy-derivatives may have a natural source (e.g., Marsh et al., 2005). Observational

5 studies on natural marine food chains (Wolkers et al., 2004) have also suggested that some

6 degradative capacity for some BDE congeners may exist in ringed seals, and components of a

7 cytochrome P-450 system (which could contribute to BDE degradation) exist in both grey

8 and harbour seals (Addison and Brodie, 1984; Addison et al, 1986). However, the

9 significance of possible differences in degradative capacity among the species discussed here

10 is impossible to assess.

\section{Acknowledgments}

13 The authors thank DFO's Regional Contaminants Laboratory chemists and laboratory 14 assistants involved in the processing and analyses of these samples. The financial support of 15 the Environmental Sciences Strategic Research Fund (Fisheries and Oceans Canada), the 16 Health Canada Toxic Substances Research Initiative Program (TSRI), and the regional 17 Fisheries and Oceans funding available to the Regional Dioxin Laboratory at IOS made this 18 work possible and is appreciated.

\section{References}

22 Addison R.F. 1989. Organochlorines and marine mammal reproduction. Can. J. Fish. Aquat. Sci. 46, 360-368. 
1 Addison R.F. \& Brodie P.F. 1977. Organochlorine residues in maternal blubber, milk and pup blubber from grey seals (Halichoerus grypus) from Sable Island, Nova Scotia. J. Fish. Res. Bd. Canada 34, 937 - 941.

Addison R.F. and Brodie P.F. 1984. Characterization of ethoxyresorufin-O-de-ethylase in grey seal, Halichoerus grypus. Comp. Biochem. Physiol. 79C, 261-263.

Addison R.F. \& Brodie P.F. 1987. Transfer of organochlorine residues from blubber through the circulatory system to milk in the lactating grey seal Halichoerus grypus. Can. J. Fish. Aquat. Sci. 44, 782 - 786.

Addison R.F. \& Stobo W.T. 2001. Trends in organochlorine residue concentrations and burdens in grey seals (Halichoerus grypus) from Sable Island, NS, Canada between 1974 and 1 994. Environ. Poll. 112, 505-513.

Addison R.F., Brodie P.F., Edwards A.J. and Sadler M.C. 1986. Mixed function oxidase activity in the harbour seal (Phoca vitulina) from Sable Island, NS. Comp. Biochem. Physiol. $85 \mathrm{C}, 121-124$.

Addison R.F., Ikonomou M.G. \& Stobo W.T. 1999. Polychlorinated dibenzo-p-dioxins and furans and non-ortho and mono-ortho chlorine substituted polychlorinated biphenyls in grey seals (Halichoerus grypus) from Sable Island, Nova Scotia, in 1995. Mar. Env. Res. 47, 225 - 240.

Addison R F., Ikonomou M.G. \& Smith T.G. 2005. PCDD/F and PCB in harbour seals (Phoca vitulina) from British Columbia: response to exposure to pulp mill effluents. Mar. Env. Res. 59, 165-176. 
1 Bidleman T.F., Cotham W.E., Addison R.F. and Zinck M.E. 1992. Organic contaminants in the Northwest Atlantic atmosphere at Sable Island, Nova Scoitia, 1988-89. Chemosphere 24, 1389-1412

Boon, J. P., Lewis, W E., Tjoen-A-Choy, M. R., Allchin, C.R., Law, R.J., De Boer, J., Ten Hallers-Tjabbes, C. C; Zegers, B. N. 2002. Levels of polybrominated diphenyl ether (PBDE) flame retardants in animals representing different trophic levels of the North Sea food Web. Environ. Sci. Technol. 36, 4025-4032

Braekevelt E., Tittlemier S.A. \& Tomy G.T. 2003. Direct measurement of octanol-water partition coefficients of some environmentally relevant brominated diphenyl ether

de Wit, C.A., Alaee, M. and Muir, D.C.G. 2006. Levels and trends of brominated flame retardants in the Arctic. Chemosphere 64, 209-233.

Hites R.A. 2004. Polybrominated diphenyl ethers in the environment and in people: a metaanalysis of concentrations. Environ. Sci. Technol. 38, 945-956.

Ikonomou, M.G.; Fraser, T.L.; Crewe, N.F.; Fischer, M.B.; Rogers, I.H.; He, T.; Sather, P.J. and Lamb, R.F. 2001. A Comprehensive Multiresidue Ultra-Trace Analytical Method, Based on HRGC/HRMS, for the Determination of PCDDs, PCDFs, PCBs,

21 Ikonomou M.G., Rayne S. \& Addison R.F. 2002. Exponential increases of the brominated 22 flame retardants, polybrominated diphenyl ethers, in the Canadian Arctic from 1981 to 2000. Environ. Sci. Technol. 36, 1886 - 1892. 
1 Iverson S.J., Harnosh M. and Bowen W.D. 1995. Lipoprotein lipase actvity and its

2 relationship to high milk fat transfer during lactation in seals. J. Compar. Physiol. B $3 \quad 165,384-395$.

4 Isosaari P., Lundebye A.-K., Ritchie G., Lie O., Kiviranta H., and Vartiainen T. 2005.

5 Dietary accumulation efficiencies and biotransformation of polybrominated diphenyl ethers in farmed Atlantic salmon (Salmo salar). Food additives and contaminants, 22, 829-37.

Kajiwara N., Ueno D., Takahashi A., Baba N., Tanabe S. 2004. Polybrominated diphenyl ethers and organochlorines in archived Northern Fur Seal samples from the Pacific Coast of Japan, 1972-1998. Environ. Sci. Technol. 38, 3804-3809.

Law R.J., Alaee M., Allchin C.R., Boon J.P., Lebeuf M., Lepom P., Stern G.A. 2003. Levels and trends of polybrominated diphenylethers and other brominated flame retardants in wildlife. Environ. Int. 29, 757-770.

Lebeuf M., Gouteux B., Measures L. and Trottier S. (2004). Levels and temporal trends (1988-1999) of polybrominated diphenyl ethers in beluga whales (Delphinapterus leucas) from the St. Lawrence Estuary, Canada. Environ. Sci. Technol. 38, 29712977.

Marsh G., Athanasiadou M., Bergman A., Asplund L. 2005. Identification of hydroxylated and methoxylated polybrominated diphenyl ethers in Baltic Sea salmon (Salmo salar) blood. Environ. Sci. Technol. 38, 10-18.

Niimi A.J. \& Oliver B.G. 1988. Influence of molecular weight and molecular volume on dietary absorption efficiency of chemicals by fishes. Can. J. Fish. Aquat. Sci. 45, 222-227. 
1 Pauly, D., Trites, A.W., Capuli, E. and Christensen V. 1998. Diet composition and trophic levels of marine mammals. ICES J. Mar. Sci. 55, 467 - 481.

\section{Rayne, S., Ikonomou, M.G., Ellis, G.M., Barrett-Lennard, L.G. \& Ross, P.S. 2004.} PBDEs, PBBs and PCNs in three communities of free-Ranging killer whales (Orcinus orca) from the Northeastern Pacific Ocean. Environ. Sci. Technol 38, 4293-4299.

6 She, J., Petreas M., Winkler J., Visita P., McKinney M., Kopec D. (2002). PBDEs in the San Francisco Bay Area: measurements in harbor seal blubber and human breast adipose tissue. Chemosphere 46, 697-707.

Smith T.G. (1987). The ringed seal, Phoca hispida, of the Canadian western Arctic. Bull. Fish. Res. Bd. Canada, 216.

Stapleton H.M., Letcher R.J., Li J., and Baker J.E. 2004a. Dietary accumulation and metabolism of polybrominated diphenyl ethers by juvenile carp (Cyprinus carpio)

Stapleton H.M., Letcher R.J., Baker J.E. 2004b. Debromination of polybrominated diphenyl

Wolkers H., Van Bavel ., Derocher A.E., Wiig O., Kovacs K.M., Lydersen C. and Lindstroem G. 2004. Congener-specific accumulation and food chain transfer of polybrominated diphenyl ethers in two Arctic food chains. Environ. Sci. Technol. $38,1667-1674$. 
1 Table 1: Major PBDE congeners and congener groups (pg/g lipid) in blubber of mother and

2 pup grey seals (Halichoerus grypus) and calculated transfer (pup conc. as \% maternal conc.)

3 from Sable Island, NS, in 1995. Data quoted to 3 significant figures as mean \pm s.d. $(\mathrm{n}=5$

4 unless otherwise stated) or as range (pup maturity). ND, not determined. 5

\begin{tabular}{|c|c|c|c|}
\hline Group: & Mothers & Pups & $\begin{array}{l}\text { Pup blubber conc. } \\
\text { as } \% \text { maternal }\end{array}$ \\
\hline \multicolumn{4}{|l|}{ PBDE congener or } \\
\hline Age (y) & $13.8 \pm 3.70$ & Stage III-V & \\
\hline $\begin{array}{l}\text { Blubber thickness } \\
(\mathrm{cm})\end{array}$ & $2.66 \pm 0.300$ & $4.82 \pm 0.680$ & \\
\hline Total mono-BDE & ND & ND & \\
\hline Total di-BDE & $15.3 \pm$ & $14.1 \pm 7.48$ & $100 \pm 25.1$ \\
\hline BDE 17 & $119 \pm 65.6$ & $114 \pm 74.5$ & \\
\hline BDE $28 / 33$ & $634 \pm 383$ & $437 \pm 276$ & \\
\hline Total tri-BDE & $877 \pm 623$ & $555 \pm 336$ & $66.1 \pm 17.4$ \\
\hline BDE 47 & $69700 \pm 30400$ & $39500 \pm 21100$ & \\
\hline BDE 66 & $177 \pm 100$ & $51.8 \pm 16.9(n=4)$ & \\
\hline BDE 75 & $40.3 \pm 1.21(n=3)$ & $11.1,5.30(\mathrm{n}=2)$ & \\
\hline Total tetra-BDE & $70200 \pm 30800$ & $39600 \pm 21100$ & $55.1 \pm 11.9$ \\
\hline BDE 99 & $10700 \pm 7250$ & $3920 \pm 2520$ & \\
\hline
\end{tabular}




\begin{tabular}{|c|c|c|c|}
\hline BDE 100 & $8730 \pm 3920$ & $2710 \pm 1390$ & \\
\hline Total penta-BDE & $20800 \pm 11200$ & $7060 \pm 4000$ & $33.4 \pm 8.53$ \\
\hline BDE 153 & $9430 \pm 6420$ & $1200 \pm 700$ & \\
\hline BDE 154 & $8350 \pm 5600$ & $1250 \pm 940$ & \\
\hline BDE 155 & $2010 \pm 1470$ & $290 \pm 195$ & \\
\hline Total hexa-BDE & $20000 \pm 13100$ & $2800 \pm 1820$ & $13.8 \pm 3.65$ \\
\hline Unidentified hepta- & $527 \pm 480$ & $32.0 \pm 14.1$ & \\
\hline \multicolumn{4}{|l|}{ BDE II } \\
\hline Total hepta-BDE & $539 \pm 492$ & $33.8 \pm 17.3$ & 15.6 \\
\hline Total di- to hepta- & $112000 \pm 55200$ & $50000 \pm 26800$ & \\
\hline
\end{tabular}


1 Table 2: PBDE congener and congener group concentrations (pg/g lipid) in harbour

2 seals (Phoca vitulina) from Strait of Georgia (SoG) and Quatsino Sd. (QS), British

3 Columbia in 1991-92. Sexes have been combined at each site. Data are quoted to 3

4 significant figures and presented as mean \pm s.d. (no of samples). $P$ is probability (by

$5 t$-test) of spatial differences arising by chance. SoG/QS is ratio of mean

6 concentrations at the two sites.

7

BDE group

Sampling period:

No. of samples taken:

Age (y)

Blubber thickness (mm)

total di-BDE

BDE 17

BDE 28/33

total tri-BDE

BDE 47

BDE 66

BDE 75

total tetra-BDE

BDE 99

BDE 100

total penta-BDE
Harbour seal, SoG

1991-92

9F, 4M

$4.90 \pm 5.10(13)$

$18.5 \pm 6.1(13)$

$26.0 \pm 10.8(8)$

$325 \pm 132(12)$

$1420 \pm 486(12)$

$1,770 \pm 529(12)$

$225,000 \pm 94,300(13)$

$568 \pm 280$ (12)

$60.4 \pm 38.5$ (4)

$$
229,000 \pm 98,000
$$

$53,800 \pm 27,100$

$16,600 \pm 6,300(13)$

$70,400 \pm 31,800(13)$
Harbour seal, QS

1991-92

$3 F, 4 M$

$8.40 \pm 4.90(7)$

$38.1 \pm 13.0(7)$

$20.5 \pm 18.1(6)$

NS

1.3

$53.7 \pm 31.8(7)$

$350 \pm 148(7)$

$417 \pm 184(5)$

$<0.01$

4.2

$18,700 \pm 7730(7)$

$127 \pm 58.4(7)$

$60.2 \pm 29.4(5)$

$19,000 \pm 7,790(7) \quad<0.001$

12.0

$3,540 \pm 1,970(7)$

$1,840 \pm 844(7)$

$5,410 \pm 2,680(7) \quad<0.001$

13.0 


$\begin{array}{lccc}\text { BDE } 153 & 14,900 \pm 6460(13) & 1,830 \pm 1,310(7) \\ \text { BDE } 154 & 1,600 \pm 620(13) & 692 \pm 603(7) & \\ \text { BDE } 155 & 713 \pm 323(13) & 383 \pm 307(7) & \\ \text { total hexa-BDE } & 17,300 \pm 7,170(13) & 2,920 \pm 19707) & <0.001 \\ \text { BDE 183 } & 143 \pm 56.7 & 85.7 \pm 49.6 & \\ \text { total hepta-BDE } & 154 \pm 66.4(13) & 87.7 \pm 51.6(7) & <0.001 \\ \text { Total tri- to hepta PBDE } & 319,000 \pm 132,000(13) & 27,800 \pm 11,800(7) & <0.001\end{array}$


1 Captions for Figures.

2 Figure 1. Map of Canada showing seal sampling sites discussed in the study. QS,

3 Quatsino Sd., BC; SoG, Strait of Georgia, BC.

4

5 Figure 2. Concentrations of major brominated diphenyl ether (BDE) congeners in 6 mother and pup grey seals (Halichoerus grypus) from Sable Island, NS in 1995. Note

7 that BDE concentrations ( $y$ axis) are on a log scale to illustrate mother pup differences

8 in congeners present at concentrations over 4 orders of magnitude.

9

10 Figure 3. Mean transfer of major brominated diphenyl ether (BDE) congeners from 11 mother to pup via milk in five Sable Island grey seals (Halichoerus grypus) mother12 pup pairs as a function of $\ln \mathrm{K}_{\mathrm{o} / \mathrm{w}}$ For di- to hexa-BDE, regression has the form:

$$
\% \text { transfer }=(-32.9 \pm 2.89) \ln \mathrm{K}_{\mathrm{o} / \mathrm{w}}+271 ; \mathrm{r}=0.98, \mathrm{n}=5, P<0.01
$$

14

15 Figure 4. Concentrations of major brominated diphenyl ether (BDE) congeners in harbour seals (Phoca vitulina) from the Strait of Georgia and Quatsino Sd., BC in 1991-92. Note that BDE concentrations ( $y$ axis) are on a log scale to illustrate geographic differences in congeners present at concentrations over 4 orders of magnitude.

Figure 5. Percentage of total polybrominated diphenyl ether (PBDE) residues represented by major congener groups in Sable Island grey seals (SIGS), Holman ringed seals (HIRS), Str. of Georgia and Quatsino Sd. harbour seals (SoG Pv and QS Pv respectively) 
Fig.1

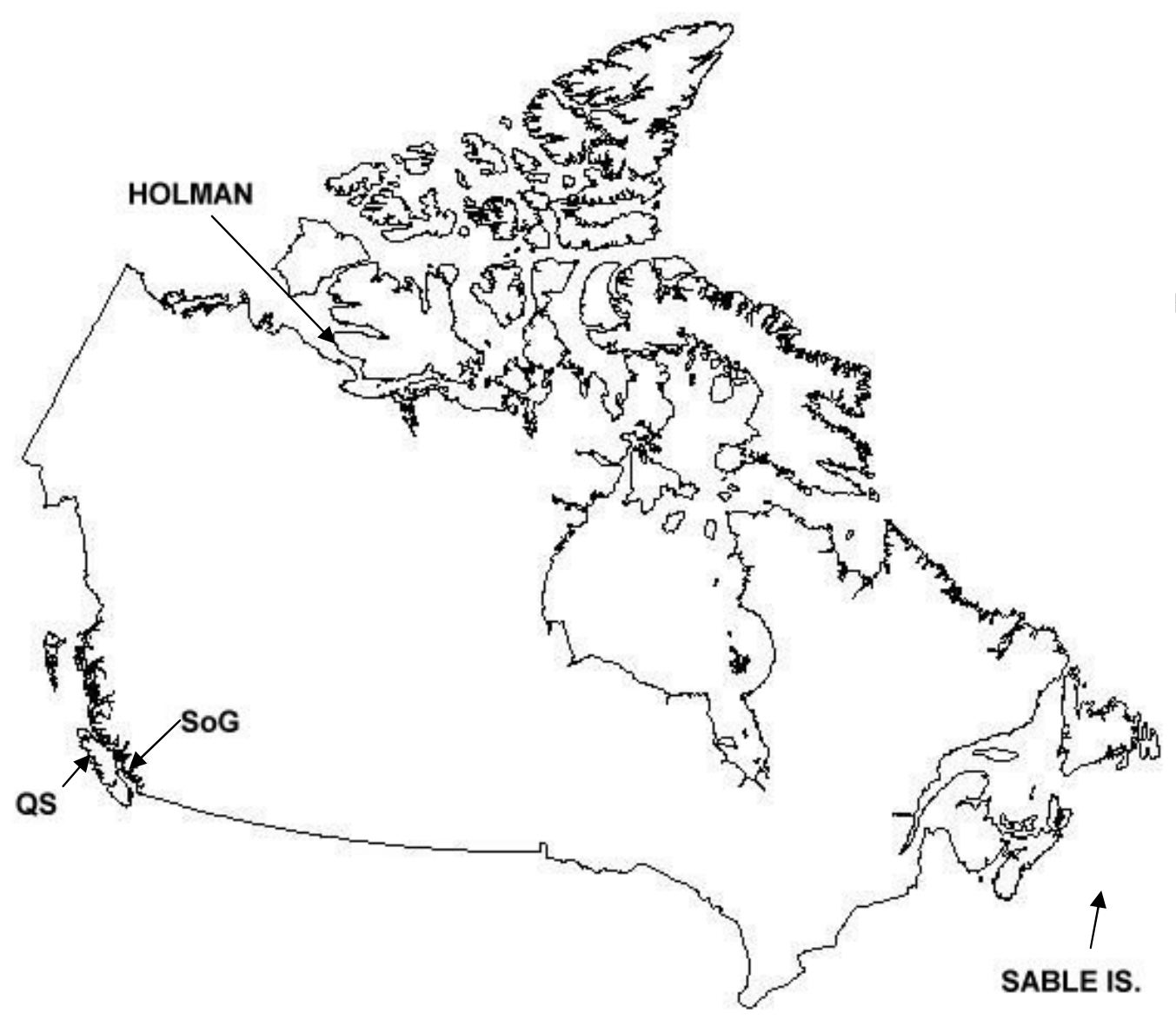

2 
$1 \quad$ Fig. 2

2

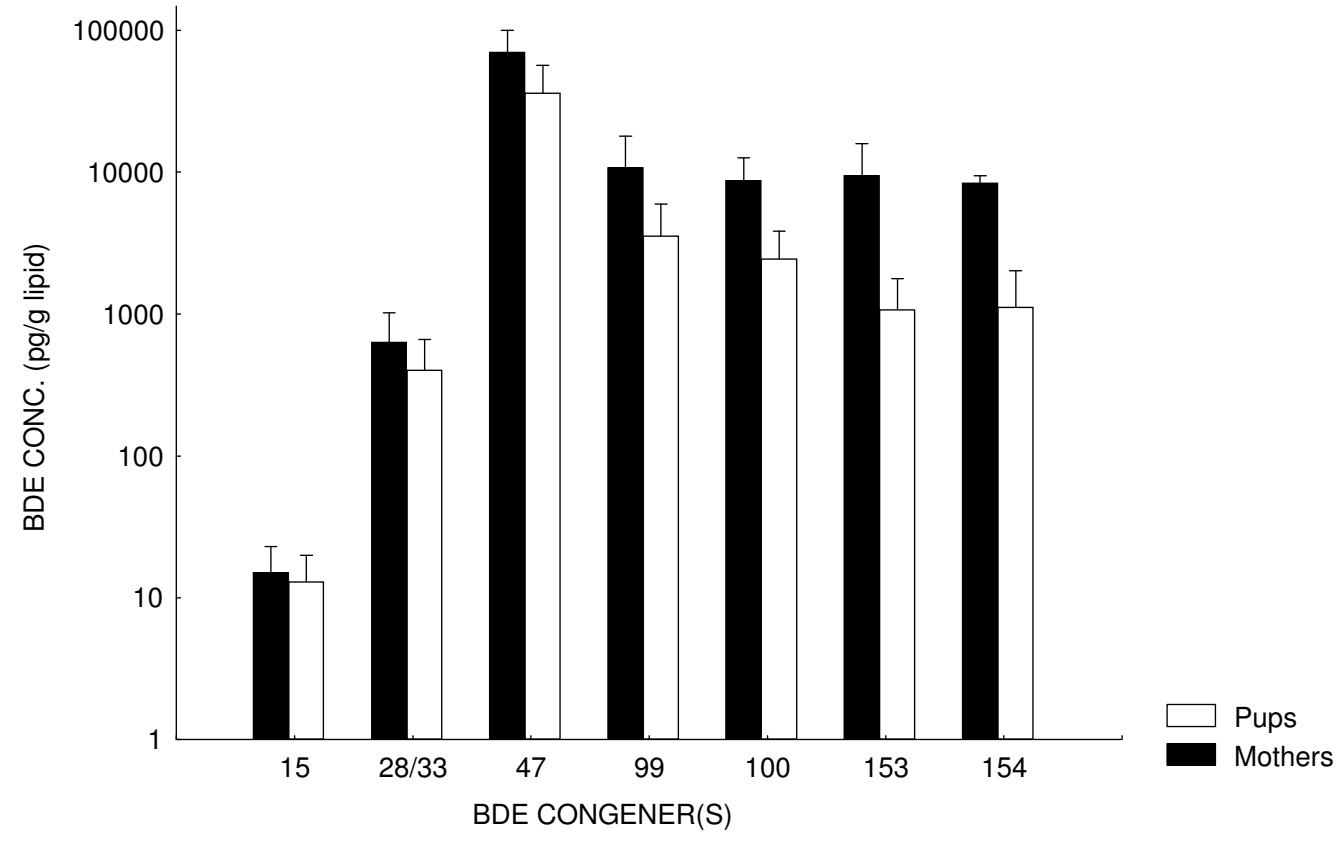

\section{3}

4 
$1 \quad$ Fig. 3

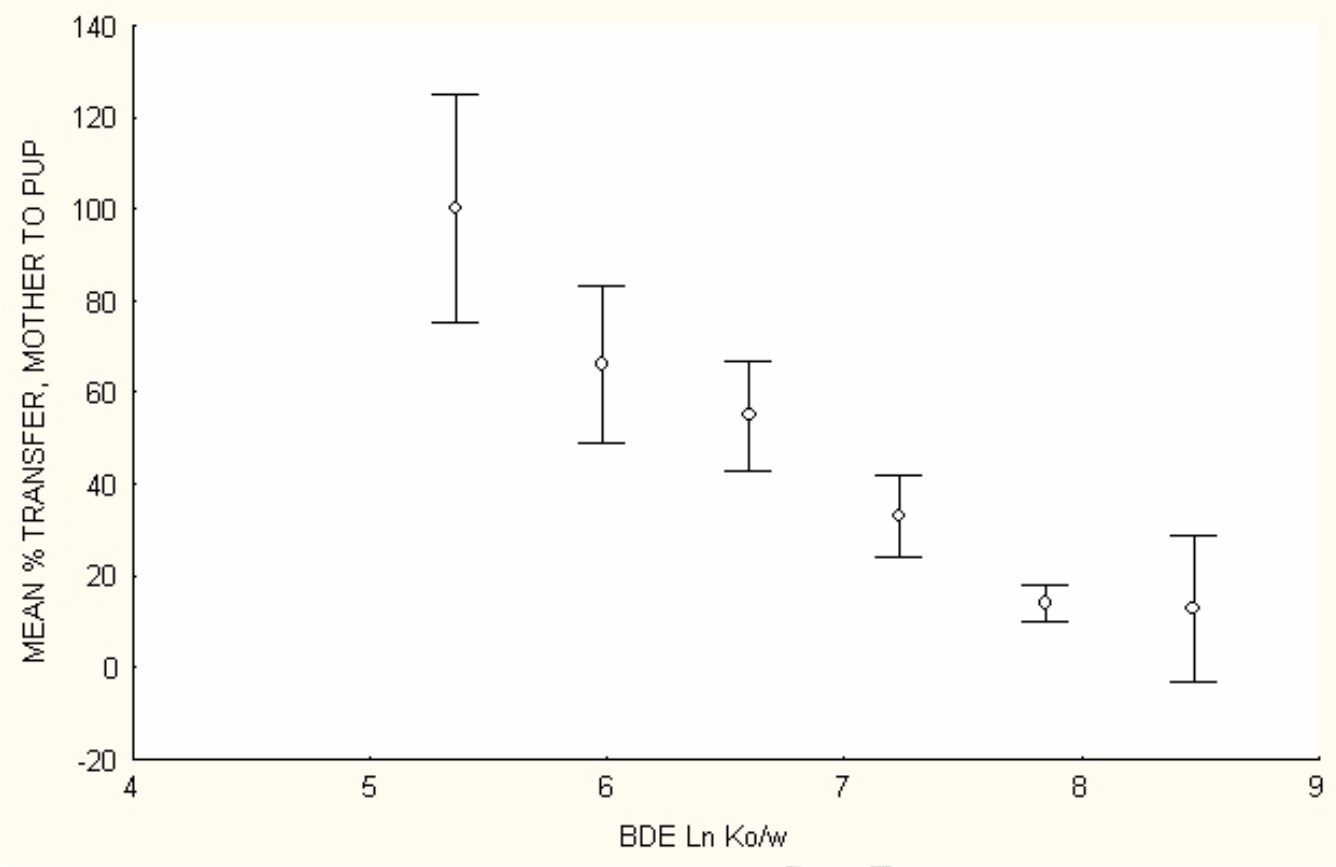

2 
$1 \quad$ Fig. 4

2

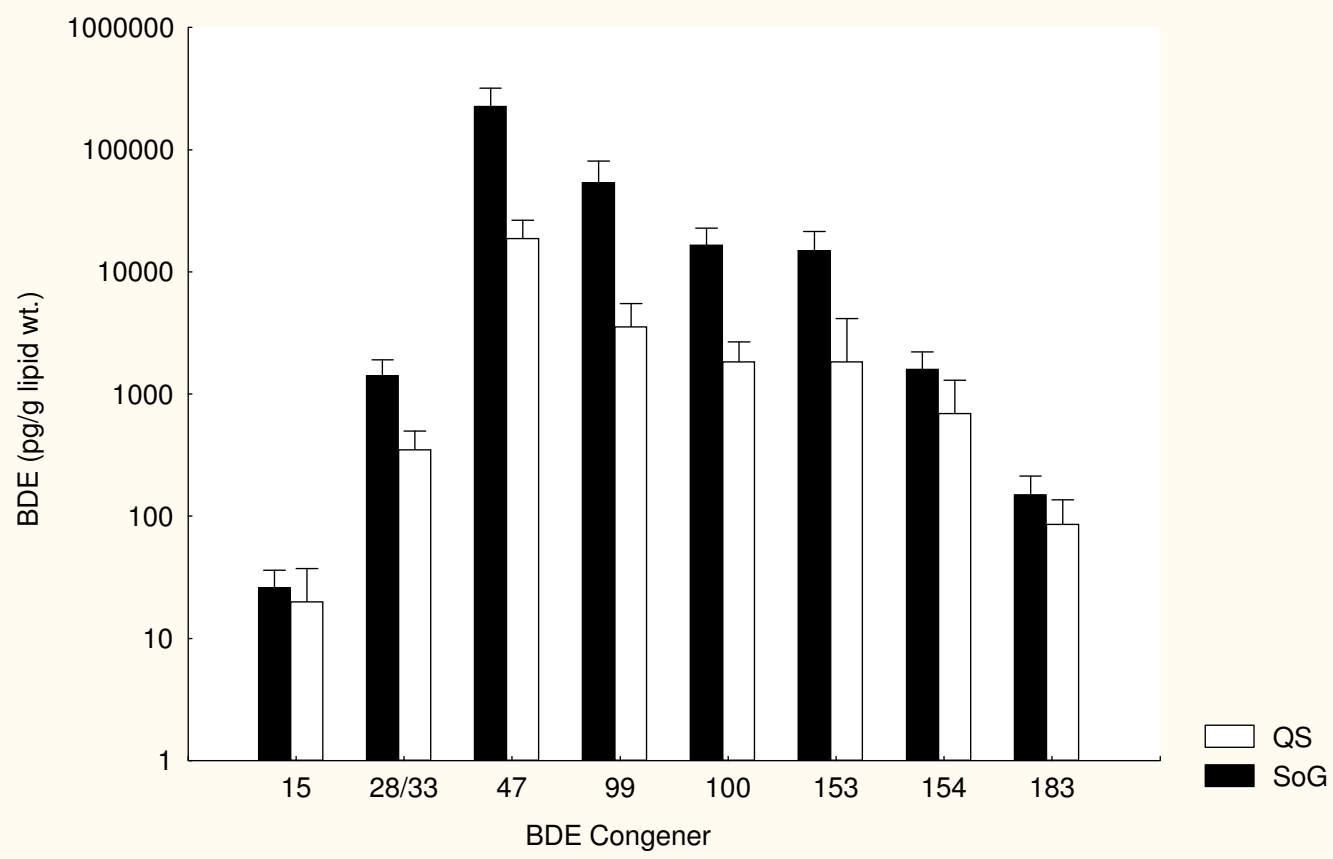

3 
Fig. 5

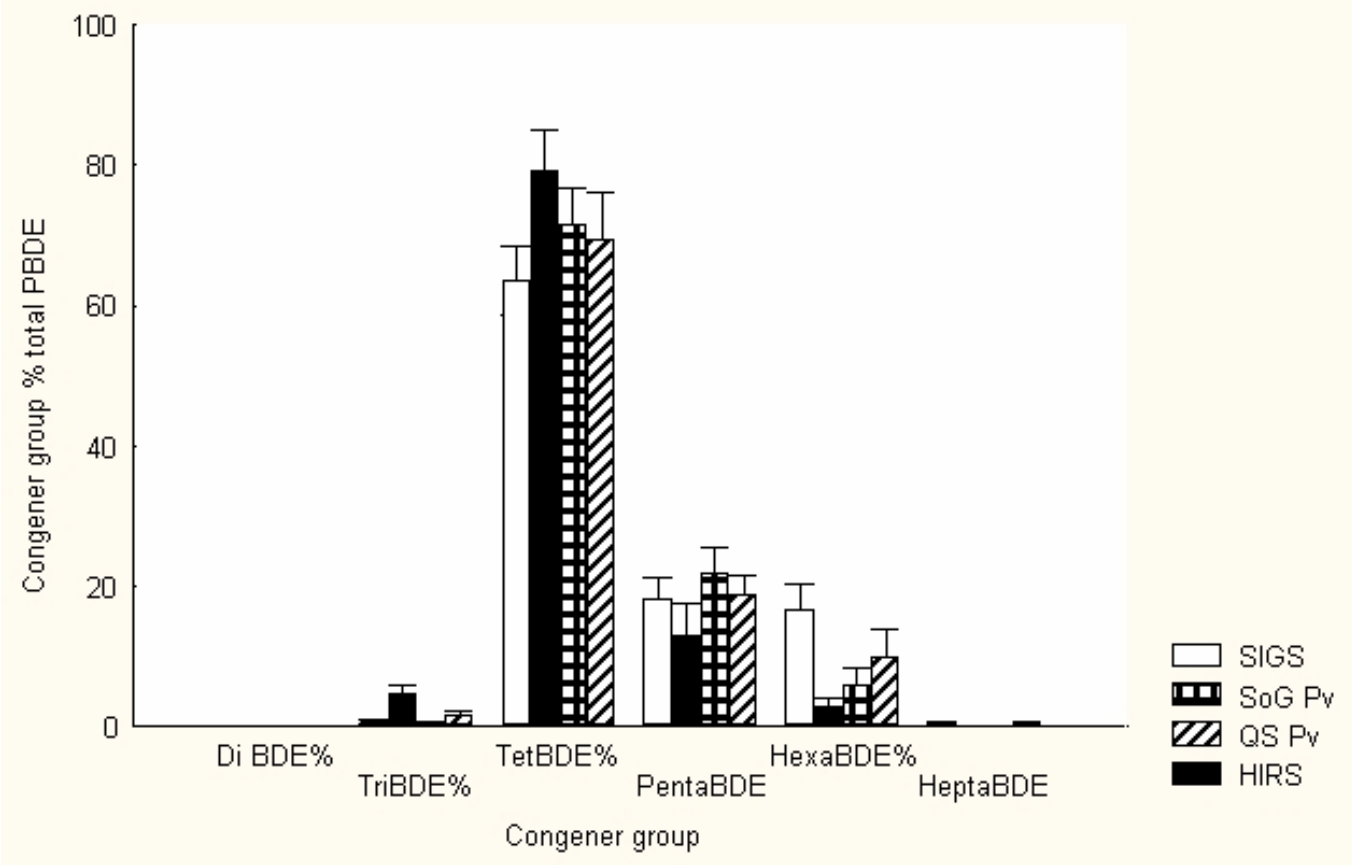

3 